\section{A Collaborative Effort to Train Green Industry Professionals}

\author{
Ann Marie VanDerZanden ${ }^{1}$, Linda R. McMahan², Neil Bell ${ }^{3}$, \\ Paul Ries ${ }^{4}$, Patty Williams ${ }^{5}$, and Aimee McAuliffe ${ }^{6}$
}

ADDITIONAL INDEX WORDs. nursery industry, landscape industry, educational training, survey, collaboration

Summary. A collaborative project between the Oregon State University Extension Service, and the green industry and allied professional organizations resulted in an educational seminar series for landscape professionals. In 2003 and 2004, the seminar series consisted of seven 3.5-hour sessions covering a range of horticultural topics and capitalized on expertise of extension personnel and green industry professionals. After the 2004 series, a survey was sent to all participants to determine attendance, overall evaluation, usefulness and applicability of information, participant learning, and behavior change as a result of the seminars. The response rate was $31 \%$. Overall, participants gave the seminars a positive rating. A majority (83\%) of respondents reported they had applied information learned at the seminar(s), and showed a significant increase in understanding of a subject as a result of participating in the seminar(s). Further, $98 \%$ of those who applied this information reported making multiple changes to their practices or recommendations to clients in the 6 months following the seminars.

$\mathrm{T}$ he green industry, which includes both production sectors (nursery and greenhouse) and service sectors (landscape design, installation and maintenance, tree care, lawn care), is a large and growing industry in the United States (Hall et al., 2005). In 2004 the nursery and greenhouse sector accounted for $\$ 26$ billion in sales (Hall et al., 2005). The industry supplies products for the 82 million households $(76 \%$ of the U.S. population) who in 2004 participated in one or more types of do-it-yourself indoor and outdoor lawn and garden activities (National Gardening Association, 2004). This large consumer group looks to multiple resources for landscape and gardening information, including newspapers, magazines, and the Internet, as well as to industry professionals (Barton et al., 1998).

${ }^{1}$ Department of Horticulture, Iowa State University, 104 Horticulture Hall, Ames, IA 50011.

${ }^{2}$ Department of Horticulture, Oregon State University.

${ }^{3}$ Department of Horticulture, Oregon State University.

${ }^{4}$ Oregon Department of Forestry.

${ }^{5}$ International Society of Arboriculture, Pacific Northwest Chapter.

${ }^{6}$ Oregon Association of Nurseries.

Acknowledgment. The authors wish to thank Debra Zaveson for assistance with this project.
Past research showed that although the media was a primary source of gardening information, consumers had little confidence $(0.32$ confidence index $)$ in the accuracy of this information (Horticulture Research Institute, 1979). In contrast, consumers had much higher confidence ( 0.73 confidence index) in nursery professionals as a source of accurate information. A more recent study (Behe and Barton, 2000) reports that trained sales staffare an important factor consumers consider when choosing a retail outlet.

The combined areas of lawn care, landscape installation, landscape design, and tree care experienced annual growth rates of 20\% between 1997 and 2004 [Associated Landscape Contractors of America (ALCA), 2004]. This growth trend was further evidenced in 2003 when $75 \%$ of industry professionals who responded to a survey by Landscape Management reported an expected increase in work from 2003 to 2004 (Brakeman, 2003). More than 700,000 people were employed in the landscape sector in 2002 (University of Georgia, 2002) and this number will likely increase as the industry expands. In many cases, this large and growing audience has both state and national certification requirements (Riley, 2003).

In 2005 ALCA merged with the Professional Lawn Care Association of
America (PLCAA) to form the Professional Landcare Network (PLANET). This large professional organization reflects the growing and interrelated components of the landscape industry and provides greater networking and expanded educational programs, including online training, as well as a national certification program (PLANET, 2005). As the industry continues to grow, and as more homeowners look to industry professionals for information, a well-educated work force is important (Severson, 2005).

A seminar series was developed in Oregon to provide educational opportunities for green industry professionals to supplement existing skills and knowledge with timely and research-based information. In addition, the seminars provided a venue for professionals to earn continuing education units (CEUs) needed for their respective certification programs.

\section{Materials and methods}

Program development. In Apr. 2003 a team of Oregon State University extension horticulture specialists and the state urban forester from the Oregon Department of Forestry (ODF) developed a proposal for a series of educational seminars and a plan to engage representatives of the green industry in Oregon. Three industry associations, the Pacific Northwest Chapter of the International Society of Arboriculture, the Oregon Landscape Contractors Association, and the Oregon Association of Nurseries, were contacted via phone and then with a follow up e-mail including a copy of the proposal. In addition to describing the vision for the seminars, we asked for their partnership in the program by 1 ) appointing one individual to serve as a member of the seminar planning team, 2) providing topic and speaker recommendations, and 3 ) promoting the seminar series to organization members. No funds were requested from any of the organizations for their participation. The arborist and landscape contractor associations appointed members to participate on the planning team.

Through a series of three plenary meetings the resulting planning team developed a list of topics and speakers, a publicity strategy, and pricing structure. The seminar series consisted of seven 3.5-h seminars (1300-1630 HR) held weekly from 4 Nov. to 16 Dec. 2003 at The Oregon Garden in 
Table 1. Topics offered during the 2003 and 2004 Willamette Valley Green Industry Seminar series.

\section{Topic}

\section{3}

4 Nov. Plant problems: The diagnostic process ${ }^{2}$

Top 25 plant problems: Disease, cultural, insect ${ }^{2}$

11 Nov. The landscape below ground (part 1): New plantings ${ }^{2}$

18 Nov. The landscape below ground (part 2): Mature plantings ${ }^{2}$

25 Nov. Flowering cherries for the wet Pacific Northwest ${ }^{\mathrm{z}}$

Biology/management of cherry bark tortrix in the Pacific Northwest

2 Dec. Plant selection and care: Drought-hardy species, native plants and new cultivars $^{\mathrm{z}}$

9 Dec. The art and function of retaining walls

16 Dec. Current topics and trends: Sudden oak death, pesticides, biostimulants ${ }^{z}$

\section{4}

2 Nov. Pruning shrubs: Techniques and advice ${ }^{\mathrm{z}}$

9 Nov. $\quad$ Pruning trees: Techniques and advice ${ }^{z}$

16 Nov. Native Willamette Valley soils and implications for landscapes ${ }^{z}$

23 Nov. Advanced plant disease diagnosis and on-line tools ${ }^{z}$

30 Nov. Turf in the Willamette Valley

7 Dec. Weevil ways and how to spite a mite

14 Dec. Native and ornamental oaks: Best selections, appropriate care and

propagation $^{\mathrm{z}}$

${ }^{2}$ Denotes seminar that qualified for International Society of Arboriculture continuing education (CEU) credit.

Silverton, Ore. (Table 1). The Oregon Garden was selected as the seminar site because of its central location to the major population centers in Oregon, its classroom facilities, and the opportunity to use parts of this 240 -acre (97.1 ha) public garden as a living laboratory. The seminars included general topics and more advanced topics that could count toward CEUs. In 2004 a representative from the Oregon Association of Nurseries was added to the planning team. Seven 3.5-h seminars were developed and held at the same location 2 Nov. to 14 Dec. 2004 (Table 1).

Each year the seminar series was publicized through newsletters of the partner organizations. Three months before the series started, a targeted mailing announcing the seminars was sent to members of these organizations. This postcard announcement included a website link where the complete registration form could be downloaded. The following month a mass mailing of the registration flyer was sent to this same membership database. The pricing structure had three tiers comprising a single seminar price, a three-seminar price, and complete series (seven seminars) price (Table 2 ). There was an "early bird" and regular rate to encourage early registration and companies who registered three or more employees received a $10 \%$ discount.
Program evaluation. In consultation with Oregon State University's internal review board, a 10-question survey instrument was developed and approved (L. Lincoln, personal communication). Survey questions were designed to gather information on seminar attendance, overall evaluation of the seminars, usefulness and applicability of information, behavior change as a result of participating in the seminars, and suggestions for future seminar topics. The survey consisted of closed-ended and open-ended questions and questions formatted into a 15-point Likert scale (Likert, 1932). In May 2005 surveys were mailed to all 220 participants from the 2003 and 2004 programs. Data collection was completed July 2005. Descriptive statistics and a paired $t$ test were computed using InStat 3.0 (GraphPad Software, San Diego).

Table 2. Pricing structure implemented for the 2003 and 2004 Willamette Valley Green Industry Seminar series.

Early-bird Regular price $(\$)$ price $(\$)$

\begin{tabular}{lrr} 
Individual seminar & 30 & 40 \\
Any three seminars & 75 & 100 \\
All seven seminars & 180 & 240 \\
\hline
\end{tabular}

\section{Results and discussion}

Of the 220 surveys, 69 were returned and usable for a response rate of $31 \%$. The majority of respondents $(61 \%)$ attended two to four seminars, while $26 \%$ attended only one seminar, $9 \%$ attended five to eight seminars, and the remaining $4 \%$ attended nine or more seminars. Most participants registered under the three-seminar pricing structure, and the majority registered via mail by completing the registration flyer they received as part of the mass mailing 1 month before the seminar series started.

Overall participants rated the value of the seminars to them personally as $9.8(0=$ not valuable; $15=$ extremely valuable). When asked if they would recommend the seminars to professional colleagues, the average response was $10.2(0=$ not at all; $15=$ with great enthusiasm). The written comments indicated that topics covered, seminar length, and event location were appropriate. Specific comments reflected a desire for more advanced seminars in tree care, nursery production, and pest and disease diagnostics and management, as well as general information on selection and care of native plants, and additional opportunities for hands-on learning.

Respondents were asked to rate their understanding of the subject(s) before attending the seminar(s) and after attending the seminar(s) using the same scale $(0=$ very low understanding; $15=$ very high understanding). They completed this question based on the number of seminars they attended. Responses of participants who attended multiple seminars were averaged over subjects. To evaluate a change in understanding of a seminar subject(s) before and after participation, a paired $t$ test was completed. A Kolmogorov-Smirnov two-sample test confirmed a normal distribution. Participants showed a significant increase in understanding of a subject(s) as a result of the seminar(s) 7.8 and 10.6 , before and after, respectively $(\mathrm{t}$ $=10.580 ; P<0.01 ; \mathrm{df}=66)$.

An overwhelming majority $(83 \%)$ reported they had applied information learned at the seminars that resulted in a moderate change $(7.6)(0=$ not at all; $15=$ completely changed) in their practices or recommendations to clients. Of these 55 participants who had applied the information, all but one 


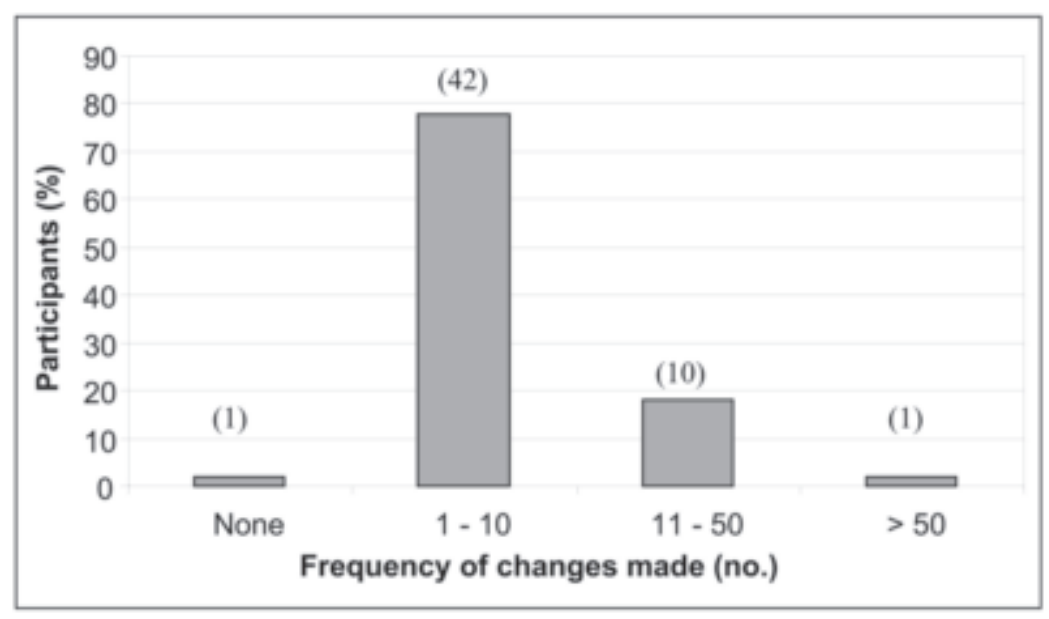

Fig. 1. Number of times participants made changes in their practices and recommendations to clients 6 months after participating in the Willamette Valley Green Industry Seminar series.

reported implementing some type of change. The majority (78\%) reported changing their practices $1-10$ times in the 6 months following seminar participation (Fig.1).

A key benefit to this collaborative program is the opportunity to augment the knowledge and skills of Oregon's green industry professionals with timely and research-based information. This transfer of research-based information is a high priority for Oregon State University and other extension programs nationwide. Engaging members of the green industry organizations early in the program planning process allowed the Oregon State University Extension Service to tailor the programming to better meet industry's educational needs. For example, green industry members of the planning team voiced a need for more education in the area of woody plant care and landscape problem diagnosis. Seminar topics in both 2003 and 2004 reflected this need.

Additionally, the combination of general and specific topics made the seminars appealing to industry personnel with a range of experience and expertise. Working directly with the representative from the Pacific Northwest Chapter of the International Society of Arboriculture resulted in approval of numerous seminars, seven in 2003 and five in 2004, that met that society's extensive recertification requirements. Other professional organizations have a more flexible approach to certification and members of those organizations submitted the necessary documentation for their certification program after attending the seminar(s).

Comments from seminar participants were constructive and included numerous suggestions for future seminars. As a result, the program is continuing in Oregon. In 2004 the program concept was adopted in Washington State by green industry organizations in two different regions of the state. Expansion of the program from these areas is planned for northern Idaho and British Columbia in 2005. Additionally, the program concept is currently being reviewed by the Iowa Nursery and Landscape Association in cooperation with the Iowa State University extension program.

\section{Literature cited}

Associated Landscape Contractors of America. 2004. ALCA's report on landscape industry growth: Trends and buying practices in the consumer market 2004 . Assoc. Landscape Contractors Amer., Herdon, Va.

Barton, S.S., J.R. Brooker, C.R. Hall, and S.C. Turner. 1998. Review of customer preference research in the nursery and landscape industry. J. Environ. Hort. 16(2):118-124.

Behe, B. and S. Barton. 2000. Consumer perceptions of product and service quality attributes in six U.S. states. J. Environ. Hort. 18(2):71-78.

Brakeman, L. 2003. 2003 State of the industry report. Landscape Mgt. 6 Oct. 2005. <http://www.landscapemanagement.net/landscape/article/articleDetail. jsp?id=70209>

Hall, C.R., A.W. Hodges, and J.J. Haydu. 2005. Economic impacts of the green industry in the United States. Natl. Urban and Community For. Advisory Committee. 4 Nov. 2005. <http://www.utextension. utk.edu/hbin/greenimpact.html>.

Horticulture Research Institute. 1979. Nursery consumer profile: Research summary. Hort. Res. Inst., Washington, D.C.

Likert, R. 1932. A technique for measurement of attitudes. Archives Psychology 140:5-55.

National Gardening Association. 2004. National Gardening Association's 2004 gardening survey. Natl. Gardening Assn., South Burlington, Vt.

Professional Landcare Network. 2005. PLANET Professional Landcare Network. 6 Oct. 2005. <http://www.landcarenetwork.org/cms/home.html>

Riley, M. 2003. Advantage: Certification. Landscape Mgt. 6 Oct. 2005. <http://www.landscapemanagement. net/landscape/article/articleDetail. jsp $? \mathrm{id}=56025$ \&pageID $=2>$.

Severson, C. 2005. Special report: What your customers really think. Lawn Landscape. Feb.:57-71.

University of Georgia, Small Business Development Center. 2002. Applied research industry fact sheets-landscaping services. North Amer. Ind. Classification System 561730.6 Oct. 2005. <http://www.sbdc. uga.edu/pdfs/landscaping2.pdf>. 